\title{
HARMONISASI KEBIJAKAN KURIKULUM PENDIDIKAN ISLAM DAN KURIKULUM PENDIDIKAN NASIONAL
}

\author{
Istianah Masruroh Kobandaha ${ }^{1}$, Firman Sidik ${ }^{2}$ \\ ${ }^{12}$ Institut Agama Islam Negeri Sultan Amai Gorontalo \\ Email: isti.tytykkobandaha@gmail.com
}

\begin{abstract}
ABSTRAK
Artikel ini membahas tentang kebijakan kurikulum pendidikan Islam dan pendidikan Nasional. Menurut penulis, kurikulum menjadi menarik untuk dikaji karena fenomena selama ini terlihat tidak akur, yang disebabkan adanya jurang dikotomis antara keduanya yang dalam ranah praktis semakin membuat hubungan keduannya saling mengklaim dan bersaing untuk membuktikan mana yang lebih baik padahal menurut hemat penulis, kedua sistem tersebut harusnya berada dalam posisi yang tidak sedang bersaing namun harus dalam posisi bersama-sama memajukan dan mencerdaskan manusia. Adapun tujuan tulisan ini adalah untuk melihat sejauh mana harmonisasi antara kedua kurikulum tersebut. Sedangkan metode yang digunakan adalah konten analisis isi dengan berbagai literature yang dikaji dengan pendekatan teoritis dan filosofis. Hasil dari penelitian ini adalah kurilulum pendidikan Islam dan nasional berada dalam suatu sistem yang sama dan bukan untuk dipertentangkan, sehingga dengan adanya hubungan yang harmonis akan mampu membangun sebuah peradaban yang lebih baik, dan menjadikan dunia pendidikan menjadi lokomotif dalam perubahan kehidupan manusia.
\end{abstract}

Kata Kunci: Harmonisasi, Kebijakan, kurikulum pendidikan Islam, kurikulum Pendidikan Nasional.

\begin{abstract}
This article discusses the policy of the Islamic education curriculum and national education. According to the author, the curriculum is interesting to study because the phenomenon so far does not seem to get along, which is due to a dichotomous gap between the two which in the practical realm makes the relationship between the two of them claim and compete to prove which one is better even though in the author's opinion, the two systems should be. are in a position that is not competing but must be in a position to jointly advance and educate humans. The purpose of this paper is to see the extent of the harmonization between the two curricula. While the method used is content analysis content with various literature studied with theoretical and philosophical approaches. The result of this research is that the curilulum of Islamic and national education is in the same system and not to be contradicted, so that a harmonious relationship will be able to build a better civilization and turn the world of education into a locomotive in changing human life.
\end{abstract}

Keywords: Harmonization, Policy, Islamic education curriculum, National Education curriculum. 


\section{PENDAHULUAN}

Kurikulum merupakan komponen yang ada dalam dunia pendidikan yang ditujukan untuk mengarahkan sebuah proses pendidikan agar selalu berada dalam koridornya. Oleh karena itu, kurikulum menjadi penting keberadaannya sebab, menjadi kompas bagi pelaku pendidikan untuk menentukan arah dan orientasi pendidikan yang akan di lakukan. Kaitan dengan hal tersebut, di Indonesia terdapat yang namanya dualisme sistem pendidikan, yang kemudian hal tersebut berdampak pada terciptanya dikotomi pendidikan dimana pendidikan Islam bermuara pada Kementerian Agama, sedangkan pendidikan umum berada di bawah naungan Kementerian Pendidikan dan Kebudayaan, yang kemudian masing-masing dari kementerian tersebut memiliki kebijakan kurikulum sendiri, walaupun masih tetap berada dalam Sistem Pendidikan Nasional.

Selain itu, kurikulum merupakan salah satu komponen yang sangat penting keberadaannya dalam suatu sistem pendidikan, karena kurikulum merupakan alat untuk mencapai tujuan pendidikan dan sekaligus menjadi pedoman dalam proses pembelajaran untuk semua jenis dan level pendidikan yang ada dari pendidikan dasar sampai pada pendidikan tinggi. Oleh karena itu, agar semua dapat berjalan dan berhasil maka perlu untuk dilakukan harmonisasi antara satu dengan lainnya agar kemudian kebijakan kurikulum yang digunakan dapat selalu relevan serta bisa memenuhi segala kebutuhan yang diperlukan demi tercapainya sebuah pendidikan yang berkualitas

Dari uraian di atas, penulis tertarik untuk mendalami dan menganalisis terkait kurikulum yang ada dalam Sistem Pendidikan Nasional, sehingga dapat menemui sinkronasi antara kurikulum pendidikan Islam dan kurikulum pendidikan umum, sehingga kegelisahan akademik terkait adanya dualisme sistem pendidikan tersebut dapat sedikit mendapat pencerahan dan solusi terkait dualisme tersebut yang selama ini seolah-olah berdiri sendiri-sendiri.

\section{METODE}

Metode yang digunakan dalam tulisan ini adalah konten analisis isi yang diambil dari dengan berbagai literature yang dikaji dengan menggunakan pendekatan teoritis dan filosofis. Noeng Muhajir yang mengatakan bahwa, dalam kajian literatur selain bentuk kajian yang memerlukan kebermaknaan empirik, diperlukan pengolahan secara teoritis dan filosofis. ${ }^{1}$

\section{KURIKULUM PENDIDIKAN ISLAM}

Secara harfiah kurikulum berasal dari bahasa latin, curriculum yang berarti bahan pengajaran. Selanjutnya kata kurikulum ini telah menjadi istilah yang digunakan dalam menunjukan sejumlah mata pelajaran yang disusun secara

\footnotetext{
${ }^{1}$ Noeng Muhadjir, Metode Penelitian, (Yogyakarta: Rake Sarasin, 2011), hlm. 101.
} 
sistematis dan harus ditempuh untuk mencapai suatu gelar atau untuk mendapatkan ijazah, sedangkan dalam bahasa arab, kata kurikulum bisa diungkapkan dengan kata "manhaj" yang berarti jalan yang terang yang dilalui oleh manusia pada berbagai bidang kehidupan. Sedangkan arti "manhaj"/ kurikulum dalam pendidikan islam sebagaimana yang terdapat dalam kamus alTarbiyah adalah seperangkat perencanaan dan media yang dijadikan acuan oleh lembaga pendidikan dalam mewujudkan tujuan-tujuan pendidikan. ${ }^{2}$

Seiring berkembangnya ilmu pengetahuan dan kemajuan dunia pendidikan, definisi kurikulum di atas kemudian di pandang ketinggalan zaman. Saylor dan Alexander sebagaimana di kutip oleh S Nasution mengemukakan bahwa kurikulum tidak hanya memuat sejumlah mata pelajaran, akan tetapi juga termasuk di dalamnya segala usaha sekolah untuk mencapai tujuan yang diinginkan, baik usaha tersebut di lingkungan sekolah ataupun di luar sekolah. ${ }^{3}$ Karena pendidikan tidak lagi dibutuhkan hanya sekedar proses tranformasi ilmu pengetahuan dan budaya, lebih dari itu secara mendesak pendidikan di tuntut untuk berperan penting dalam memberikan solusi kepada peserta didik berkenaan dengan kebutuhan, masa depan serta tantangan-tantangan yang akan mereka hadapi.

Pendapat tentang kurikulum yang sebutkan terakhir di atas, sejalan dengan apa yang utarakan Hasan Langgulung. Menurutnya, kurikulum adalah sejumlah pengalaman pendidikan, kebudayaan, sosial, olah raga, dan kesenian baik yang berada di dalam maupun di luar kelas yang dikelola oleh sekolah. ${ }^{4}$ Selanjutnya dari berbagai teori tentang kurikulum yang dikemukakan oleh para ahli pendidikan, Hasan Langgulung mengemukakan pendapat yang lebih spesifik terkait kurikulum pendidikan Agama Islam, menurutnya kurikulum pendidikan Agama Islam bersifat fungsional, yang tujuannya mengeluarkan dan membentuk manusia muslim, kenal agama dan tuhanNya, berakhlak al-Qur'an, sanggup menikmati kehidupan yang mulia dalam masyarakat, dan sanggup memberi dan membina masyarakat itu serta mendorong dan mengembangkan kehidupan sekitar. Adapun karakter dari kurikulum pendidikan islam, sebagaimana yang dikemukakan dalam bukunya ahmad janan antara lain: 1) mengedapankan tujuan agama islam dan akhlak. Karakteristik ini mewarnai karakteristik-karakteristik lain, utamanya yang berorientasi pada pendidikan tauhid dan penanaman nilainilai, 2) selaras dengan fitrah manusia termasuk berkenaan dengan pembawaan, bakat, jenis kelamin, potensi, dan perkembangan psiko-fisik, 3) merespons dan mengantisipasi kebutuhan nyata peserta didik dan masyarakat, serta

\footnotetext{
${ }^{2}$ Ramayulis, Ilmu Pendidikan Islam, (Jakarta: Kalam Mulia, 2008). hlm. 61

${ }^{3}$ S. Nasution, Pengembangan Kurikulum Pendidikan, (Bandung: Citra Adirya Bakti, 1991). hlm. 9

${ }^{4}$ Hasan Langgulung, Asas-asas Pendidikan Islam. (Jakarta: Pustaka al-Husna, 1987). hlm. 483-484
} 
mengusahakan solusi terkait dengan masa depan dan perubahan sosial yang terjadi secara terus-menerus, 4) mendorong penggunaan metode-metode yang dinamis, fleksibel dan membuat peserta didik belajar didorong oleh kesadaran dan hati senang, termasuk dalam menghadapi pelajaran-pelajaran agama, 5) materinya realistik, terjangkau disusun secara runtun sesuai dengan psiko-fisik, tingkat dan nilai-nilai agamis, 6) mengembangkan keseimbangan antara aspek intelektual, emosional, dan spiritual, 7) menghindarkan peserta didik dari pemahaman dikotomik terhadap ilmu pengetahuan agama dan ilmu-ilmu yang lain, sekaligus menghindarkan peserta didik dari pemahaman agama parsial yang dapat mengakibatkan peserta didik bersikap ekstrem. ${ }^{5}$

\section{ORIENTASI KURIKULUM PENDIDIKAN ISLAM}

Pada dasarnya, orientasi kurikulum pendidikan Islam dapat dirangkum menjadi lima, yaitu orientasi pada pelestarian nilai-nilai, orientasi pada kebutuhan sosial, orientasi pada tenaga kerja, orientasi pada peserta didik, dan orientasi pada masa depan dan perkembangan ilmu pengetahuan dan teknologi.

\section{Orientasi Pelestarian Nilai}

Dalam pandangan Islam, nilai terbagi atas dua macam, yaitu nilai yang turun dari Allah SWT, yang disebut nilai ilahiyah, dan nilai yang tumbuh dan berkembang dari peradaban manusia sendiri yang disebut dengan nilai insaniyah. Kedua nilai tersebut selanjutnya membentuk norma-norma atau kaidah-kaidah kehidupan yang dianut dan melembaga pada masyarakat yang mendukungnya.

2. Orientasi pada Kebutuhan Sosial

Masyarakat yang maju adalah masyarakat yang ditandai oleh munculnya berbagai peradaban dan kebudayaan sehingga masyarakat tersebut mengalami perubahan dan perkembangan yang pesat walaupun perkembangan itu tidak mencapai pada titik kulminasi. Hal ini karena kehidupan adalah berkembang, tanpa perkembangan berarti tidak ada kehidupan. Maka harus memberikan kontribusi positif dalam perkembangan sosial dan kebutuhannya, sehingga output dari lembaga pendidikan mampu menjawab dan mengatasi masalah-masalah yang dihadapi masyarakat.

\section{Orientasi pada Tenaga Kerja}

Manusia sebagai makhluk biologis mempunyai unsur mekanisme jasmani yang membutuhkan kebutuhan-kebutuhan lahiriah, misalnya makan minum, bertempat tinggal yang layak, dan kebutuhan biologis lainnya. Kebutuhankebutuhan tersebut harus terpenuhi secara layak, dan salah satu di antara persiapan untuk mendapatkan pemenuhan kebutuhan yang layak adalah melalui pendidikan. Dengan pendidikan, pengalaman dan pengetahuan seseorang

${ }^{5}$ Ahmad Janan Asifudin, Mengungkit Pilar-Pilar Pendidikan Islam(Tinjauan Filosofis), (Yogyakarta: Suka Press, 2010). hlm. 117-118 
bertambah dan dapat menentukan kualitas dan kuantitas kerja seseorang. Hal ini karena dunia kerja dewasa ini semakin banyak saingan, dan jumlah perkembangan penduduk jauh lebih pesat dari penyediaan lapangan kerja.

4. Orientasi pada Peserta Didik

Orientasi ini memberikan kompas pada kurikulum untuk memenuhi kebutuhan peserta didik yang disesuaikan dengan bakat, minat, dan potensi yang dimilikinya, serta kebutuhan peserta didik. Orientasi ini diarahkan kepada pembinaan tiga dimensi peserta didiknya. a) Dimensi kepribadian sebagai manusia, yaitu kemampuan untuk menjaga integritas antara sikap, tingkah laku, etika, dan moralitas. b) Dimensi produktivitas yang menyangkut apa yang dihasilkan anak didik dalam jumlah yang lebih banyak, kualitas yang lebih baik setelah ia menamatkan pendidikannya. c) Dimensi kreativitas yang menyangkut kemampuan anak didik untuk berpikir dan berbuat, menciptakan sesuatu yang berguna bagi diri sendiri dan masyarakat.

5. Orientasi pada Masa Depan Pekembangan (IPTEK)

Kemajuan suatu zaman ditandai oleh kemajuan ilmu pengetahuan dan teknologi serta produk-produk yang dihasilkannya. Hampir semua kehidupan dewasa ini tidak lepas dari keterlibatan IPTEK, mulai dari kehidupan yang paling sederhana sampai kehidupan dan peradaban yang paling tinggi. Dengan IPTEK, masalah yang rumit menjadi lebih mudah, masalah yang tidak berguna menjadi lebih berguna, masalah yang using dan kemudian dibumbui dengan produk IPTEK menjadi lebih menarik. ${ }^{6}$

\section{PRINSIP KURIKULUM PENDIDIKAN ISLAM}

Dalam penyusunan kurikulum, semestinya harus memperhatikan prinsipprinsip yang dapat mewarnai kurikulum pendidikan Islam. Prinsip-prinsip tersebut adalah sebagai berikut:

1. Prinsip berasaskan Islam, termasuk ajaran dan nilai-nilainya. Maka setiap yang berkaitan dengan kurikulum, termasuk falsafah, tujuan-tujuan, kandungan-kandungan, metode mengajar, cara-cara perlakuan, dan hubungan-hubungan yang berlaku dalam lembaga-lembaga pendidikan harus berdasarkan pada agama dan akhlak Islam.

2. Prinsip mengarah kepada tujuan adalah seluruh aktivitas dalam kurikulum diarahkan untuk mencapai tujuan yang dirumuskan sebelumnya.

3. Prinsip integritas antara mata pelajaran, pengalaman-pengalaman, dan aktivitas yang terkandung di dalam kurikulum, begitu pula dengan

${ }^{6}$ Abdul Mujib dan Jusuf Mudzakir, Ilmu Pendidikan Islam, (Jakarta: Kencana Prenada Media, 2010), hlm. 135. 
pertautan antara kandungan kurikulum dengan kebutuhan murid juga kebutuhan masyarakat.

4. Prinsip relevansi, yaitu adanya kesesuaian pendidikan dengan lingkungan hidup peserta didik, relevansi dengan kehidupan masa sekarang dan akan dating, relevansi dengan tuntutan pekerjaan.

5. Prinsip fleksibilitas, adalah terdapat ruang gerak yang memberikan sedikit kebebasan dalam bertindak, baik yang berorientasi pada fleksibelitas pemilihan program pendidikan maupun dalam mengembangkan program pengajaran.

6. Prinsip integritas, adalah kurikulum tersebut dapat menghasilkan manusia seutuhnya, manusia yang mampu menintegrasikan antara fakultas dzikir dan fakultas pikir, serta manusia yang dapat menyelaraskan struktur kehidupan dunia dan struktur kehidupan akhirat.

7. Prinsip efisiensi, adalah agar kurikulum dapat mendayagunakan waktu, tenaga, dana, dan sumber lain secara cermat, tepat, memadai, dan dapat memenuhi harapan.

8. Prinsip kontinuitas dan kemitraan adalah bagaimana susunan kurikulum yang terdiri dari bagian yang berkelanjutan dengan kaitan-kaitan kurikulum lainnya, baik secara vertikal (perjenjangan, tahapan) maupun secara horizontal.

9. Prinsip individualitas adalah bagaimana kurikulum memperhatikan perbedaan pembawaan dan lingkungan anak pada umumnya yang meliputi seluruh aspek pribadi anak didik, seperti perbedaan jasmani, watak, inteligensi, bakat serta kelebihan dan kekurangannya.

10. Prinsip kesamaan memperoleh kesempatan, dan demokratis adalah bagaimana kurikulum dapat memberdayakan semua peserta didik memperoleh pengetahuan, keterampilan, dan sikap yang sangat diutamakan. Seluruh peserta didik dari berbagai kelompok seperti kelompok yang kurang beruntung secara ekonomi dan sosial yang memerlukan bantuan khusus, berbakat, dan unggul berhak menerima pendidikan yang tepat sesuai dengan kemampuan dan kecepatannya.

11. Prinsip kedinamisan, adalah agar kurikulum tidak statis, tetapi dapat mengikuti perkembangan ilmu pengetahuan dan perubahan sosial.

12. Prinsip keseimbangan, adalah bagaimana kurikulum dapat mengembangkan sikap potensi peserta didik secara harmonis.

13. Prinsip efektivitas, adalah agar kurikulum dapat menunjang efektivitas guru yang mengajar dan peserta didik yang belajar. ${ }^{7}$

\footnotetext{
${ }^{7}$ Ramayulis, Ilmu Pendidikan Islam, (Jakarta: Kalam Kurnia, 2008), hlm. 161-162.
} 


\section{CIRI-CIRI KURIKULUM PENDIDIKAN ISLAM}

Menurut Omar Mohammad al-Toumy al-Syaibani, bahwa kurikulum pendidikan Islam, memiliki ciri-ciri sebagai berikut:

1. Menonjolkan tujuan agama dan akhlak pada berbagai tujuannya. Kandungan, metode, alat, dan tekniknya bercorak agama.

2. Meluaskan cakupannya dan menyeluruh kandungannya, yaitu kurikulum yang benar-benar mencerminkan semangat, pemikiran dan ajaran yang menyeluruh. Di samping itu, ia juga luas perhatiannya. Ia memerhatikan bimbingan, dan pengembangan terhadap segala aspek pribadi pelajar dari segi intelektual, psikologis, sosial, dan spiritual.

3. Bersikap seimbang di antara berbagai ilmu yang dikandung dalam kurikulum yang akan digunakan. Selain itu, juga harus seimbang antara pengetahuan yang berguna bagi pengembangan individual dan pengembangan sosial.

4. Bersifat menyeluruh dalam menata seluruh mata pelajaran yang diperlukan oleh peserta didik, seperti seni, bahasa,dll.

5. Kurikulum yang disusun selalu disesuaikan dengan alam sekitar, budaya, dan sosial masyarakat, serta minat dan bakat peserta didik. ${ }^{8}$

\section{KURIKULUM NASIONAL}

Kurikulum menurut Ahmad Janan adalah sebuah perencanaan pendidikan formal atau non formal yang terdiri dari sejumlah komponen yang sangat relevan untuk membantu tercapainya tujuan lembaga pendidikan formal atau non formal yang bersangkutan. ${ }^{9}$ Kurikulum juga merupakan pedoman yang di dalamnya terkandung berbagai konsep dan landasan bagi institusi untuk tercapainya sebuah tujuan. ${ }^{10}$

Sedangkan dalam UU Sistem Pendidikan Nasional No 20 Tahun 2003 dijelaskan bahwa kurikulum merupakan seperangkat rencana dan pengaturan mengenai tujuan, isi dan bahan pelajaran serta cara yang digunakan sebagai pedoman penyelenggaraan kegiatan pembelajaran untuk mencapai tujuan pendidikan tertentu. ${ }^{11}$ Sedangkan dalam pasal 36 ayat 3 di jelaskan lebih detail lagi bahwa kurikulum disusun sesuai dengan jenjang dan jenis pendidikan dalam kerangka Negara Kesatuan Republik Indonesia dengan memperhatikan:

\footnotetext{
${ }^{8}$ Oemar Mohammad al-Toumy al-Syaibany, Filsafat Pendidikan Islam, (Jakarta: Bulan Bintang, 1997). hlm. 490-512

${ }^{9}$ Ahmad Janan Asifudin, Mengungkit Pilar-Pilar Pendidikan Islam..hlm 118

10 Sukiman, Pengembangan Kurikulum, Teori Dan Praktik Pada Perguruan Tinggi, (Yogyakarta: Fakultas Ilmu Tarbiyah Dan Keguruan UIN Sunan Kalijaga, 2013), hlm. 3.

11 Darmaningtyas Dkk, Membongkar Ideologi Pendidikan, Jelajah Undang-Undang Sistem Pendidikan Nasional, (Yogyakarta: Resolusi Press, 2014), hlm. 237.
} 
1. Peningkatan iman dan takwa.

2. Peningkatan akhlak mulia.

3. Peningkatan potensi, kecerdasan, dan minat peserta didik.

4. Keragaman potensi daerah dan lingkungan.

5. Tuntutan pembangunan daerah dan nasional.

6. Tuntutan dunia kerja.

7. Perkembangan ilmu pengetahuan.

8. Agama.

9. Dinamika perkembangan global.

10. Persatuan nasional dan nilai-nilai kebangsaan. ${ }^{12}$

Kaitan dengan itu kurikulum sebagai suatu rencana atau program tertulis harus memiliki aspek ideal dimana, keidealan trsebut minimal memiliki unsur sebagai berikut, pertama, merumuskan tujuan dan kompetensi yang harus dimiliki oleh peserta didik. Jika tidak dapat kita bayangkan bahwa tanpa tujuan yang jelas sebagai rambu-rambu maka guru akan kesulitan menentukan dan merencanakan program pembelajaran, kedua, menentukan isi atau materi pelajaran yang harus dikuasai untuk mencapai tujuan atau penguasaan kompetensi, ketiga, menyusun strategi pembelajaran untuk guru dan peserta didik sebagai upaya pencapaian tujuan, keempat, menentukan keberhasilan pencapaian tujuan atau kompetensi. ${ }^{13}$

Itulah beberapa poin ideal yang minimal harus dimiliki oleh sebuah kurikulum, sehingga apa yang menjadi konsep dan gagasan dalam kurikulum dapat terlaksana dengan efektif dan efisien dalam realitas pendidikan, terkhusus bagi pelaku pendidikan yaitu guru dan peserta didik.

\section{KOMPONEN KURIKULUM}

Ahmad Tafsir dalam Ramayulis menyatakan bahwa komponen kurikulum terdiri dari: 1) tujuan, merupakan hal penting dalam kurikulum sehingga harus berisi minimal tiga domain, yaitu kognitif, afektif, dan psikomotor. Namun dalam pendidikan Islam, domain afektif lebih utama dari yang lainnya. 2) isi, Berupa materi pembelajaran yang diprogram untuk mencapai tujuan pendidikan yang telah ditetapkan. Materi tersebut disusun ke dalam silabus, dan dalam mengaplikasikannya dicantumkan pula dalam satuan pembelajaran dan perencanaan pembelajaran.3) metode, atau proses belajar mengajar, dan 4) evaluasi. $^{14}$

\footnotetext{
${ }^{12}$ Ibid, hlm. 252.

${ }^{13}$ Wina Sanjaya, Kurikulum dan Pembelajaran, (Jakarta: Kencana, 2010), hlm. 22

${ }^{14}$ Ramayulis, Ilmu Pendidikan Islam, ...... hlm. 161-162.
} 
Selain hal tersebut di atas, komponen kurikulum dirangkum dari berbagai literaur menemukan empat komponen yaitu, Tujuan, dimana tujuan ini merupakan hal yang ingin dicapai oleh suatu lembaga pendidikan secara keseluruhan, yang meliputi tujuan kognitif, afektif, dan psikomotorik. ${ }^{15}$ Namun demikian para pemikir Islam membagi tujuan ini menjadi dua, yaitu pertama ditujukan untuk keagamaan dalam hal ini memfokuskan pada pembentukan pribadi muslim yang sanggup melaksanakan syariat Islam melalui proses pendidikan spiritual menuju ma'rifat kepada Allah swt, kedua, tujuan yang berorientasi pada keduniaan untuk mewujudkan kehidupan sejahtera di dunia dan kemanfaatnya. ${ }^{16}$

Materi,dalam kurikulum pendidikan, materi merupakan komponen yang berfungsi untuk menunjang proses pembelajaran yang disusun secara logis dan sistematis demi terwujudnya tujuan pendidikan yang sudah ditetapkan. Adapun isi dari materi ini biasanya berupa bahan ajar yang disesuaikan dengan jenis bidang studi yang dianggap sesuai dengan standar kompetensinya, selain itu materi jika dilihat dari aspek filsafatnya juga sangat beragam, misalnya materi pembelajaran yang didasarkan pada filsafat progresivisme, pasti akan lebih berorientasi kepada hal-hal tentang kebutuhan, minat, dan kehidupan peserta didik, oleh karena itu materi pendidikan harus diambil dari peserta didik, dan oleh peserta didik itu sendiri, sedangkan materi pembelajaran yang didasarkan pada filsafat konstruktivisme, pasti materi pembelajarannya akan dikemas sedemikian rupa dalam bentuk tema atau topik-topik yang diangkat dari masalah-masalah sosial yang krusial, seperti ekonomi, sosial, bahkan tentang alam. ${ }^{17}$

Metode, dalam sebuah proses pembelajaran seorang guru haruslah memiliki metode atau cara yang digunakan untuk menunjang proses pembelajaran agar materi yang diberikan dapat membekas dalam hati dan pikiran peserta didik dan dapat tercermin dalam kehidupan sosial masyarakat, selain itu metode ini juga harus disesuaikan dan relevan dengan materi yang akan disampaikan, sebagaimana dalam ilmu pendidikan Islam, menyebutkan bahwa suatu metode itu baik jika memiliki watak dan relevansi yang senada dengan tujuan pendidikan Islam itu sendiri. ${ }^{18}$

Evaluasi, kehadiran evaluasi ini semata-mata dimaksudkan untuk menilai suatu kurikulum sebagai sebuah program pendidikan untuk mengetahui sejauh mana efisiensi, efektivitas, relevansi, dan prodduktivitas program yang dilakukan dalam mencapai tujuan pendidikan, selain itu evaluasi juga dimaksudkan sebagai

15 Anin Nurhayati, Kurikulum Inovasi, Telaah Terhadap Pengembangan Kurikulum Pesantren, (Yogyakarta: Teras, 2010), hlm. 34

16 Ibid

${ }^{17}$ Sukiman, Pengembangan Kurikulum, Teori Dan Praktik Pada Perguruan Tinggi, hlm. 17.

18 Anin Nurhayati, Kurikulum Inovasi, Telaah Terhadap Pengembangan Kurikulum Pesantren,hlm. 41. 
feedback terhadap tujuan, materi, dan metode sehingga kedepannya akan berguna untuk mengembangkan kurikulum. ${ }^{19}$

\section{HARMONISASI KEBIJAKAN KURIKULUM PENDIDIKAN ISLAM DAN KURIKULUM PENDIDIKAN NASIONAL}

Pendidikan Islam sebagai sub sistem dari pendidikan Nasional tentu memiliki hubungan erat dengan pendidikan nasional. Proses yang dijalani dalam dunia Pendidikan Islam selalu sesuai dengan apa yang kehendaki oleh pendidikan Nasional. Hal ini sebagaimana tersirat secara Yuridis, dimana posisi pendidikan Agama (Islam) berada pada posisi yang sangat setrategis, baik pada UUSPN No.2 tahun 1989 maupun dalam UUSPN No. 20 Tahun 2003. Pada UUSPN 1989 dinyatakan, bahwa pedidikan nasional bertujuan "mencerdaskan kehidupan bangsa dan mengembangkan manusia indonesia seutuhnya, yaitu nanusia yang beriman dan bertakwa terhadap Tukan Yang Maha Esa dan berbudi pekerti luhur, memiliki pengetahuan dan keterampilan, kesehatan jasmani dan rohani, kepribadian yang mantap dan mandiri, serta rasa tanggungjawab kemasyarakatan dan kebangsaan.

Pendidikan Islam merupakan bagian dan juga inti kurikulum pendidikan nasional, sebab pendidikan Islam pun terpadu dalam sistem pendidikan nasioanal. kenyataan tersebut pada dasarnya cukup menguntungkan bagi pendidikan Islam, sebab posisinya semakin kuat, kalau selama ini mungkin pendidikan Islam merasa tersisih, oleh karenanya dengan uu nomor tahun 2003 ini status pendidikan agama adalah sama kuatnya dengan pendidikan umum.

Sejak Kurikulum Nasional tahun 1984 diterapkan, Kurikulum Pendidikan Islam baik di Sekolah umum ataupun di Madrasah disederhanakan dengan tujuan memberikan keluwesan dalam pengembangan selanjutnya. Dimana dari kedua bentuk kurikulum tersebut baik Pendidikan Agama Islam di Sekolah umum dan di Madrasah, memiliki persamaan dan perbedaan, yang secara eksistensi tujuan dan ruang lingkup adalah sama, namun karena keluasan materi yang didukung oleh alokasi waktu yang berbeda, maka kurikulum itu akan mengalami perbedaanperbedaan yang menjadi ciri khas masing-masing.

Hal tersebut bisa dilihat pada kurikulum pendidikan Islam baik yang ada di Sekolah atau Madrasah misalnya menjadi ciri khas tersendiri bagi masyarakat Indonesia khususnya umat Islam yang ingin anak-anaknya mendapatkan pengetahuan Agama sekaligus dapat juga memiliki pengetahuan. Itulah yang kemudian menjadi karakter dan keunggulan Pendidikan Islam karena bisa mencetak individu yang memiliki orientasi dunia dan juga akhirat. Orientasi dunia ditujukan untuk mewujudkan kehidupan sejahtera di dunia dan kemanfaatnya.

19 Ali Mudlofir, Aplikasi Pengembangan Kurikulum Tingkat Satuan Pendidikan Dan Bahan Ajar Dalam Pendidikan Agama Islam, (Jakarta: Rajawali Pers, 2011), hlm. 11-12. 
Sedangkan orientasi akhirat adalah ditujukan untuk memfokuskan pada pembentukan pribadi muslim yang sanggup melaksanakan syariat Islam melalui proses pendidikan spiritual menuju ma'rifat kepada Allah swt. ${ }^{20}$

\section{PENUTUP}

Dalam setiap penyelenggaraan suatu pendidikan formal haruslah memiliki yang namanya perencanaan, atau kurikulum yang mengatur terdiri dari komponen-komponen yang relevan untuk bersama-sama mewujudkan apa yang menjadi tujuan lembaga pendidikan tersebut, oleh karena itu kurikulum harus bisa mewakili segala aspek dan unsur-unsur yang terkandung dalam pendidikan agar para pelaku atau pihak yang terkait dapat mewujudkannya dalam ranah praksis dengan penuh semangat perjuangan, dan tanggung jawab yang mendalam bahwa apa yang menjadi tujuan kurikulum harus dilaksanakan. Sehingga dengan demikian, kehadiran kurikulum pendidikan Islam sebagai subbab dari kurikulum pendidikan Nasional harus mampu bersinergi agar bisa mewujudkan cita-cita yang diamanahkan Undang-undang yaitu mencerdaskan kehidupan bangsa.

\section{DAFTAR PUSTAKA}

Al-Syaibany, Oemar Mohammad al-Toumy. Filsafat Pendidikan Islam, Jakarta: Bulan Bintang, 1997.

Asifudin, Ahmad Janan. Mengungkit Pilar-Pilar Pendidikan Islam (Tinjauan Filosofis), Yogyakarta: Suka Press, 2010.

Darmaningtyas dkk, Membongkar Ideologi Pendidikan, Jelajah Undang-Undang Sistem Pendidikan Nasional, Yogyakarta: Resolusi Press, 2014.

Langgulung, Hasan. Asas-asas Pendidikan Islam. Jakarta: Pustaka al-Husna, 1987.

Mudlofir, Ali Aplikasi Pengembangan Kurikulum Tingkat Satuan Pendidikan Dan Bahan Ajar Dalam Pendidikan Agama Islam, Jakarta: Rajawali Pers, 2011.

Muhadjir, Noeng. Metode Penelitian, Yogyakarta: Rake Sarasin, 2011.

Mujib Abdul dan Mudzakir, Jusuf Ilmu Pendidikan Islam, Jakarta: Kencana Prenada Media, 2010.

Nasution,S. Pengembangan Kurikulum Pendidikan, Bandung: Citra Adirya Bakti, 1991.

Nurhayati, Anin. Kurikulum Inovasi, Telaah Terhadap Pengembangan Kurikulum Pesantren, Yogyakarta: Teras, 2010.

Ramayulis, Ilmu Pendidikan Islam, Jakarta: Kalam Kurnia, 2008.

20 Anin Nurhayati, Kurikulum Inovasi, Telaah Terhadap Pengembangan Kurikulum Pesantren, (Yogyakarta: Teras, 2010), hlm. 34 
Sidik, F. (2020). HAKIKAT KURIKULUM DAN MATERI DALAM PENDIDIKAN ISLAM. JURNAL PENDIDIKAN ISLAM AL-ILMI, 3(2).

Sanjaya, Wina. Kurikulum dan Pembelajaran, Jakarta: Kencana, 2010.

Sukiman, Pengembangan Kurikulum, Teori Dan Praktik Pada Perguruan Tinggi, Yogyakarta: Fakultas Ilmu Tarbiyah Dan Keguruan UIN Sunan Kalijaga, 2013. 